\title{
Active Filtering and Exchange of Indoor Air by Means of Mobile Air Conditioners to Avoid Infection by The SARS Cov-2 Virus
}

\author{
Sebastian König* \\ Department of Medical Technology and Biotechnology, University of Applied Sciences, Germany
}

\begin{abstract}
*Corresponding author: Sebastian König, Department of Medical Technology and Biotechnology, Ernst-Abbe-Hochschule Jena, University of Applied Sciences, Germany.
\end{abstract}

Received Date: March 17, 2021

Published Date: May 17, 2021

\section{Problem Definition}

In not actively ventilated rooms such as in schools, air exchange is insufficient, particularly during win- ter. Under the presence of COVID-19 or to reduce the $\mathrm{CO}_{2}$ concentration, the air must be filtered and refreshed as well as possible. A tracer clearance experiment using a mobile air conditioner e.g. from KRONE Kälte + Klima VertriebsmbH Germany is supposed to determine to what extent. In Szabadi [1]. the air exchange rate $[n]=1 / h$ is introduced as a measure of air exchange. The exhaust volume flow $[\mathrm{dV} / \mathrm{dt}] \dot{\mathrm{V}}=\mathrm{m}^{3} / \mathrm{h}$ is related to room volume $[\mathrm{V}]=\mathrm{m}^{3}$. The air exchange rate $\mathrm{n}$ is a multiple of the room volume. Reference values are $n=3 / \mathrm{h}<=n<=6 / \mathrm{h}$. The air conditioner in (Figure 1) comprises an air recirculation (5) and an active air exchange (6). The recirculation may also filter and cool the air. Here, the air filter rate $[\mathrm{f}]=1 / \mathrm{h}$ serves as a measure. Both measures must be considered according to [1].

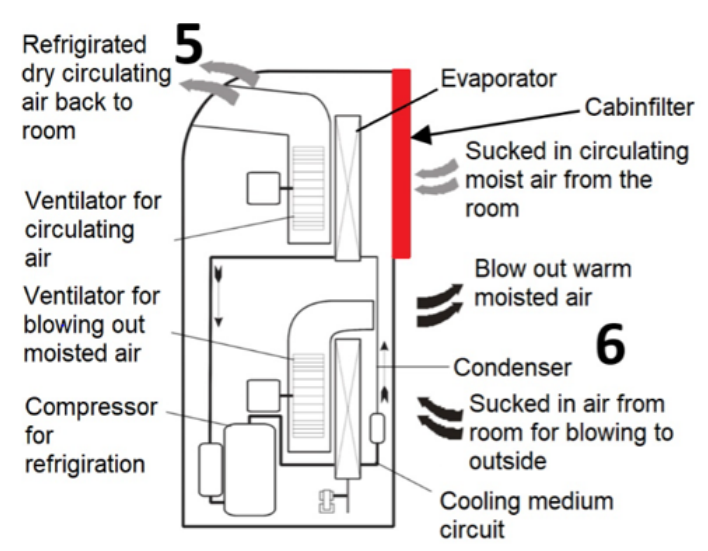

Figure 1: Cross section of a mobile air conditioner comprising two air ciruits.

\section{Setup}

A mobile air conditioner (1) in (Figure 2) actively recirculates (2) and refreshes (3) the air of the room. A ventilator (4) supports recirculation. The recirculation of air (5) in (Figure 1) also cools an dehumidifies and filters the air. The second air exchange (6) suck in the room air and blows it out of the window. The air conditioner 
GREE GPC-12-AL-R290 [2] comes with a recirculation volume flow of $\dot{v}=360 \mathrm{~m}^{3} / \mathrm{h}$ and is optimized for rooms up to floor area of $22 \mathrm{~m}^{2}$ an air exchange rate of $\mathrm{n} \approx 16 / \mathrm{h}$. The conducted measurements show effectiveness also in bigger rooms. Disco fog (EUROLITE smoke fluid -X EXTREM A2) served as a tracer replacing the aerosol. The relative fog density is measured indirectly via relative light transmission $\mathrm{T}=0 \mathrm{~T}=0 \% \ldots 100 \%$ alternativly $0 \%<=\mathrm{T}<=100 \%$ with measuring instrument TRDA 2.0 [3]. In a seminar room of $\mathrm{V}$ $=220 \mathrm{~m}^{3}$ Figure 3 , an active operating mode without refrigeration and without dehumidification is used (Figure 1\&2).

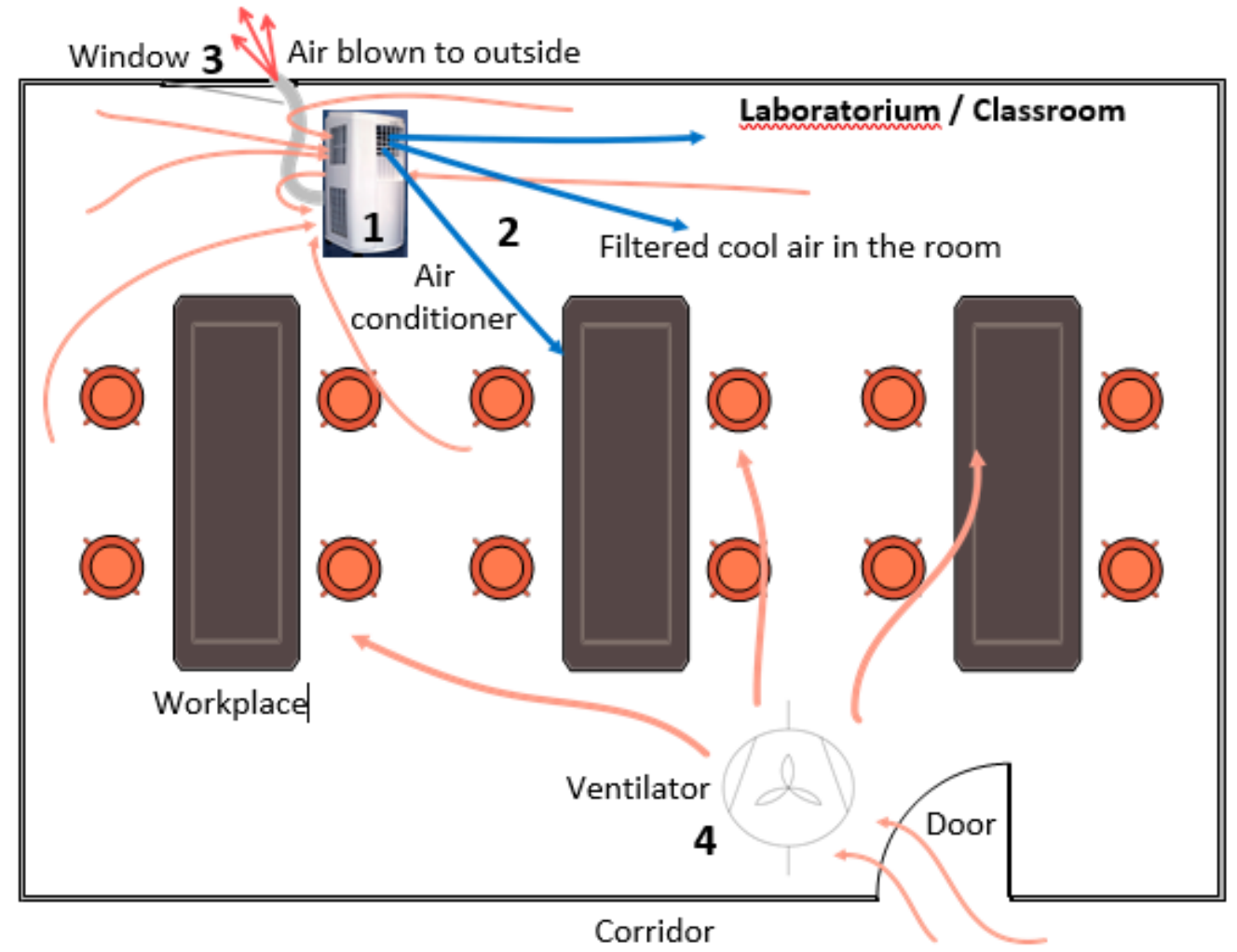

Figure 2: Concept for active ventilation of a classroom.

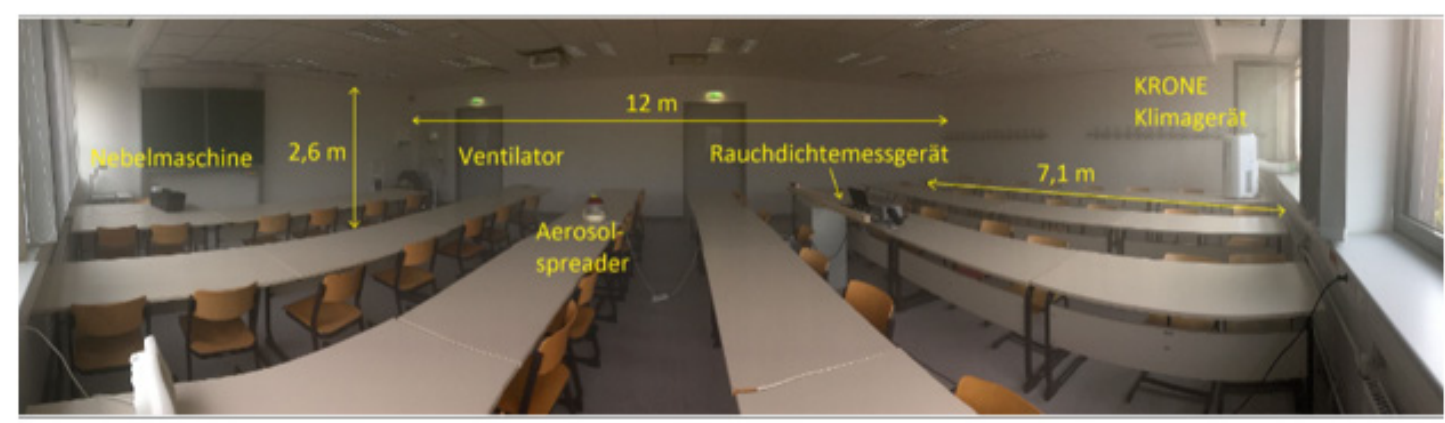

Figure 3: Experimental setup at seminar room at EAH Jena Germany.

\section{Result}

Figure 4 shows the plot of the tracer clearance process by relative light transmission as a function of 83 minutes the fog is removed completely whence $\mathrm{n}=360 \mathrm{~m}^{3} / \mathrm{h} / 220 \mathrm{~m}^{3}=1,6 / \mathrm{h}$. After $\mathrm{t}<$ $10 \mathrm{~s}$ without fog (which is $\mathrm{T}_{\mathrm{o}}=100 \%$ ) the room is filled with fog. The light transmission goes down Figure 4 shows the plot of the tracer clearance process by relative light transmission as a function of two
$\mathrm{T}<10 \%$. At the same time the air filter rate $\mathrm{f}=2 / \mathrm{h}$ has effect. As example for lecture rooms, $n \geq 8 / h$ is required. This is accomplished by stationary air conditioners. the step response of a simple mathe-

matical model $T(t)=T_{0} .\left(1-e^{-\frac{t}{\tau}}\right)$ with just one-time constant $\tau$ and a normalized light transmission $\mathrm{T}_{\mathrm{o}}=100 \%$ is plotted in red in Figure 
Fog washout with mobile air conditioner GREE GPC-12-AL-R290 at $220 \mathrm{~m}^{3}$

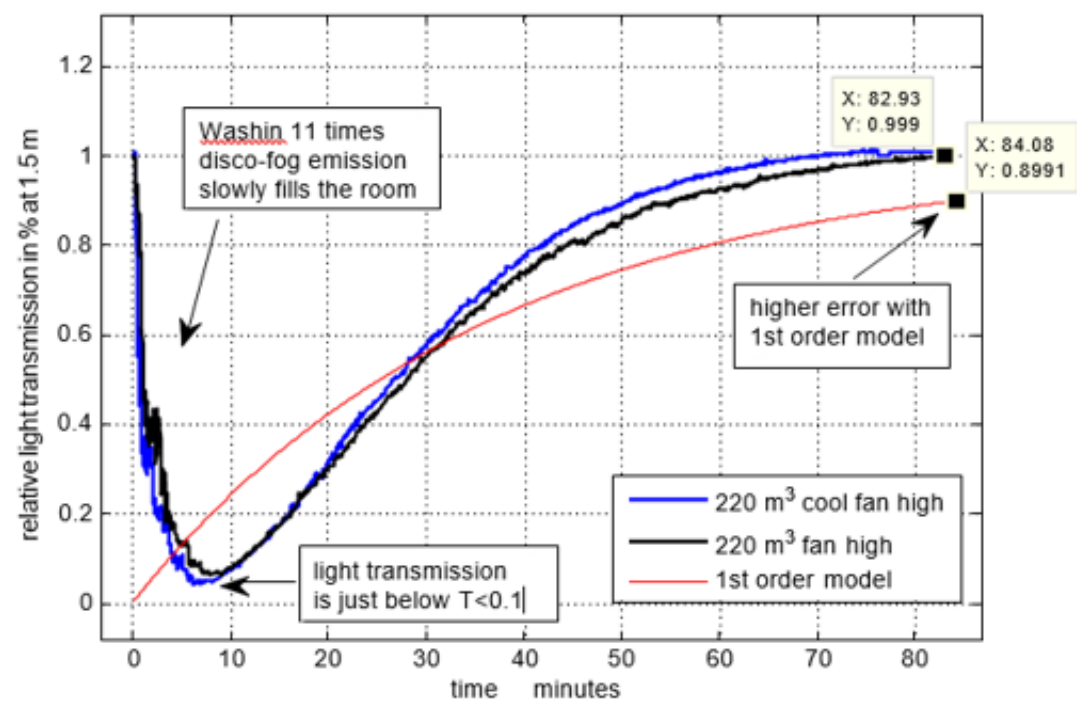

Figure 4: Time plot of relative light transmission.

The units are $[\mathrm{t}]=\min ,[\tau]=\min$ and $\left[\mathrm{T}_{0}\right]=100 \%$. The time constant $\tau$ estimated by the room volume $\mathrm{V}=220 \mathrm{~m}^{3}$ and $\mathrm{dV} / \mathrm{dt}=$ $V$, dot $=360 \mathrm{~m}^{3} / \mathrm{h}=6 \mathrm{~m}^{3} / \mathrm{min}$ as $\tau \approx 37 \mathrm{~min}$. The Error of the model is.... $-10 \%$ in practice, clearance is done faster than estimated. We recommend the use of a mobile air conditioner. During the warm seson, the mobile air conditioner may additionally refrigerate. With an additional cabin filter [5] the filtering effect can be improved (Figure 3 \& 4).

\section{Acknowledgement}

Alfons Geser (HTWK Leipzig, Germany) proofread the manuscript and Werner Schroeder (w. schroeder@krone- klima.de) donated hardware. I gratefully acknowledge their help.

\section{Conflict of Interest}

No conflict of interest.

\section{References}

1. Szabadi J, Meyer J, Dittler A (2020) Untersuchung der Minderung der Partikelkonzentration in geschlossenen Innenräumen durch einen hoch wirksamen Innenraumfilter. Institut für Mechanische Verfahrenstechnik und Mechanik.

2. Installations- und Bedienungsanleitung Mobiles Inverter-Raumklimagerät GPC12-AL-R290.

3. TRDA-Rauchdichte-Messgerät mit Lichtmesstrecke.

4. (2020) Aktiver Luftaustausch und Luftfilterung in Schulräumen mit einem mobilen Klimagerät.

5. FreciousPlus -der Innenraumfilter gegen Feinstaub, Stickoxide und Allergene. MANN Filter. 